\title{
Gündelikçi Kadınların Sosyo-ekonomik Durumları ve Beklentileri: Denizli Kent Örneği
}

\author{
Radiye Canan BAĞIŞ*
}

Öz

Bu çalışmada gündelikçi olarak ev temizliğine giden kadınların toplumsal özellikleri Denizli kent örneğinden hareketle irdelenmeye çalışılmıştır. Araştırmada, gündelikçi kadınların sosyo-ekonomik durumlarının, çalışmaya başlama nedenlerinin, işe giriş süreçlerinin, işverenleriyle ilişkilerinin, çalışma ve yoksulluk algılarının, kendi statülerini algılama biçimlerinin, boş zaman etkinlikleri ve gelecek beklentilerinin kendi bakış açılarından ortaya konulması amaçlanmıştır. Araştırma betimsel nitelikte olup nitel veri tekniklerinden derinlemesine görüşme tekniği kullanılarak gerçekleştirilmiştir. Bu bağlamda gündelikçi on kadınla bire bir mülakatlar yapılmıştır.

Anahtar kelimeler: Gündelikçi kadınlar, Ev işçileri, Ev hizmetleri, Çalışan Kadinlar.

\section{Socio-economic Situations of Charwomen and Their Expectations: Denizli City Case}

\begin{abstract}
In this study, the charwomen's social features have been tried to examine based on the example of Denizli city. The aim of this survey is to present the charwomen's socio-economic conditions, the process of application, the reasons that led them start work as charwoman, their relationships with their employers, their perception of working and poverty issues, their way of understanding their own statues, their leisure time activities and their future expectations through their own point of views. The study has descriptive quality and it was conducted by using depth interview technique, one of the qualitative data techniques. In this context, individual were made with ten charwomen.
\end{abstract}

\footnotetext{
* Dr., Pamukkale Üniversitesi Sosyoloji Anabilim Dalı Doktora Mezunu, Sosyal Bilimler Enstitüsü, rcananb@gmail.com
} 
Keywords: Charwomen, Home workers, Home services, Working women.

\section{GíRiş}

Gündelikçi olarak ev temizliği işinde çalışan kadınlar, kentsel hizmet sektörünün önemli aktörlerindendir. Ev işçisi kadınlar, düşük eğitim düzeyine ve herhangi bir mesleki niteliğe sahip olmadıkları için düşük statülü ve vasıfsız özelliğe sahip olan ev temizliği işine yönelmektedirler. Kadınları gündelikçi piyasasına iten nedenlerin başında yoksulluk gelmektedir. Dar gelirli ailelere mensup kadınlar, aile geçimine katkı sağlamak amacıyla çoğunlukla enformel yollarla çalışma hayatına giriş yapmaktadırlar. Gündelikçi kadınlar ev temizliği işinde çalışıyor olmalarına rağmen, çalışan yoksullar kategorisinde yer almaktadirlar.

Bu araştırmada öncelikle kavramsal çerçeve çizilecektir. Kavramsal çerçevede ev işi olgusuna değinilecek, ardından ev işinin ücretli ev emeğine dönüşümü tarihsel bir bağlamda ele alınacaktır. Ev hizmetlerinin tarihsel gelişiminden sonra ev temizliği işinin de içinde yer aldığı enformel işlerin özelliklerine değinilecek, kadınları enformel nitelikte olan ev temizliği işinde çalışmaya iten nedenler üzerinde durulacaktır. Araştırmanın kavramsal çerçevesi çizildikten sonra araştırmanın metodolojisine yer verilecek, ardından araştırma bulgularına geçilecektir. Araştırma bulguları, gündelikçi kadınların sosyo-ekonomik durumları, çalışma yaşamları, kendi statülerini algılayış biçimleri, boş zaman etkinlikleri ve gelecek beklentileri olmak üzere dört alt başlık altında irdelenecektir. Çalışmanın sonuç kısmında araştırma bulguları değerlendirilecektir.

\section{KAVRAMSAL ÇERÇEVE}

Ev işi, eski çağlardan itibaren kadınlara yüklenen bir iş olmuştur. İnsanların yerleşik düzene geçmesiyle, yaşam tarzlarında işbölümüne dayalı bir değişim yaşanmıştır. Cinsiyete dayalı işbölümüne göre tarım aletlerinin kullanımını üstlenen erkek, tarımsal alanda çalışma etkinliğini sürdürmüştür. Kadın, ev işleri, çocuk bakımı ve gerektiğinde erkeğe yardımcı olmak şeklinde görevler üstlenmiştir (Bağış, 2017: 11). Toplumların kapitalist toplum biçimine geçişiyle birlikte kadının özel alanı olan evinden çıkıp kamusal alana geçişi söz konusu olmuştur. Kadın, erkeğin yaptığı işleri yapmaya başlamıştır. Buna rağmen evde yemek pişirmek, temizlik yapmak gibi ev işlerini yapma görevini toplum kadına atfetmeye devam etmiştir. Oakley (1975) ev işini, daha çok kadınlar tarafından yapılan, parasal karşılığı olmayan bir emek süreci olarak tanımlamıştır. De Beauvoir’e (1952) göre ev işi, negatif temele oturan bir çalışma türü olup, temizlik, pisliğin yok edilmesi, toplama, düzensizliğin ortadan kaldırılmasına karşılık gelir.

Görünmeyen emek olarak da nitelendirilebilen ve evin kadını tarafından ücretsiz olarak yapılan ev işi, ev dışındaki bir başka kadına para karşılığında yaptırıldığında ücretli ev emeğine dönüşür. Cinsiyete dayalı iş bölümüyle temellenen ev emeğinin parayla alınıp satılan meta haline gelmesi ise onun sınıfsal bir niteliğe büründüğünü gösterir. Ücretli ev emeği, "orta sınıfın kadınlarına ev işlerinden kaçınmalarını ve hane içinde cinsiyete bağlı 
iş ayrımını görmezden gelmelerini sağlar” (Özyeğin, 2004: 36). Ücretli ev işçisi kadınların işverenleri genellikle orta sınıf aileleri olup, işyerleri ise bu orta sınıfların özel alanları olan evleridir. Farklı sınıftan gelen bu kesimlerin kendine özgü bir iş ilişkisi içinde kesişmeleri belli bir tarihsel süreçte gerçekleşmiştir.

Feodal dönemin Avrupa’sında, ev hizmetlerinde köleler ${ }^{2}$ çalıştırılmıştır. Feodal düzenin yıkılmasından sanayileşme dönemine kadar geçen sürede ev hizmetlerinde köle kullanımına devam edilmiştir. Sanayileşmeyle birlikte ev hizmetlerinde belli bir ücret karşılığında çalışan-çalıştıran ilişkisi ortaya çıkmıştır. Sanayileşme ve kentleşme yeni orta sınıf doğurmuştur. Diğer yandan tarımda makineleşme sonucu çok sayıda kadın işgücü, kırdan kente göç etmiştir. Kentlerde açığa çıkan niteliksiz kadın işgücü fazlası orta sınıf kadınların hizmetçisi olmak üzere iş aramaya başlamışlardır (Momsen, 1999). Orta-üst sınıf aileler, özellikle kadınların çalışma hayatına katılmaları durumunda, ev hizmetini belli bir ücret karşılığında, dışarıdan, kadın çalışanlardan sağlama yoluna gitmiştir. Böylece ev, ev işi için sağlanan ücretli emek ile işveren kadınların karşılaştığ bir iş yerine dönüşmüştür (Kalaycıoğlu ve Rittersberger-Tilıç, 2001: 40).

Türkiye'de ev hizmetlerinin tarihsel gelişimine bakıldığında Kapitalizm öncesi Osmanlı toplumunda ev emeği olarak ev kölelerinin kullanıldığı, Cumhuriyet’in kuruluş sürecinde hizmetçi olarak evlatlıkların kullanıldığı, kapitalizmin yaygınlaşmasıyla gündelikçilerin çalıştırıldığg görülmektedir (Özbay, 2012 akt. Çelik ve Yüce-Tar, 2016: 67). Gündelikçi emeğinin gelişimi açısından 1950'lilerin ve 1970’li yılların önemli dönemeçler olduğu söylenebilir. Bu süreçte yaşanan kentleşme ve göç olgusu, ev hizmetlerinde çalışan kadınların niceliğinde ve niteliğinde değişiklikler yaratmıştır.

Ülkemizde 1950 yılında yaşanan siyasi dönüşüm sonrası yönetime gelen kadrolar, kırda tarımın modernleştirilmesini öngörürken, kentte de sanayileşmeyi uygulamaya başlamıştır. Kentlerin cazibe merkezleri haline gelmesi beraberinde köyden kente göçü getirmiştir (Bağış, 2017: 39). Yetmişli yıllara kadar, kente yeni göç eden kadınların büyük çoğunluğu ataerkil baskıların da etkisiyle ev kadınlığ rollerini daha çok önemsemiş, ücret karşılığında çalışma onların öncelikli amacı olmamıştır. 70’lerden sonra aile geçimini sağlamakla yükümlü olan erkeğin geliri düşmeye başlayınca, kadınların çalışma isteği ve sınırlı da olsa işgücüne katılımı artmıştır (Kalaycıoğlu ve Rittersberger-Tılıç, 2001: 42). Düşük eğitim seviyesine sahip kadınların önemli bir kesimi vasıfsız ve düşük ücretli işlerde (gündelikçilik gibi) çalışmaya yönelmişlerdir.

Diğer yandan Türkiye'de yaşanan kentleşmeyle birlikte orta sınıf gelişmeye başlamıştır. Özellikle kadın ve erkeğin çalıştığı (kimi orta sınıflarda kadın ücretli bir işte çalışmıyor olsa dahi) sabit geliri olan ailelerde kadının ev işlerine ayıracak zamanı ve isteği

2 Ortaçağ toplumları köleci toplumların/kölelik düzeninin yıkılmasının ardından gelen toplum biçimidir. Üretim biçimi olarak kölelik sona ermiş olsa da Kalaycığlu ve Rittersberger- Tilıç’in (2001: 37-38) belirttiği gibi, Batı'da 17. yüzyıla kadar ev işi sadece üst sınıf kadınları söz konusu olduğunda başkalarından sağlanan bir hizmet şekline dönüşmüştür. Burada çalışan işveren ilişkisi köle-efendi niteliğindedir. 
azalmıştır. Orta sınıftan kadınlar bu gereksinimi gündelikçi kadınlardan temin etme yoluna gitmişlerdir. Yaşanan kentleşme deneyimi, orta sınıf kadınları ve köyden göç etmiş kadınları karşılıklı gereksinimler doğrultusunda işverenin evinde karşılaştırmıştır. Çalışanın işyerine dönüşen işverenin evi bir anlamda geleneksel ve modernin kesiştiği bir mekan haline gelmiştir.

Gündelikçi kadın, kentsel alanda, enformel yollarla ulaştığı ev temizliği işinde, belli bir ücret karşılığında çalışan kadın olarak tanımlanabilir. Kentsel emek gücünün bir parçası haline gelen gündelikçi kadınların çalıştığı ev hizmetleri, enformel niteliktedir. Özyeğin’in (2005: 45) çalışmasında aktardığı bir tanımlamaya göre enformel işler: "1) sermaye ile emek arasındaki kesin ayrımın; 2) her ikisi arasında mukaveleye dayanan bir ilişkinin; ve 3) ücret ödenen ve çalışma ve ödeme koşullarının yasaca düzenlendiği bir işgücünün yokluğuyla nitelendirilen iş durumlarının tümü"dür. Bu biçimde tanımlanan enformel sektör, formel ve devlet tarafından düzenlenen ekonomi dışında bütün üretimi ve ticari etkinlikleri kapsamaktadır. Gündelikçi kadınları enformel nitelikte olan ev temizliği işine iten nedenlerin başında yoksulluk gelmektedir. Yoksulluk, Suğur ve arkadaşlarının (2010: 85) belirttiği gibi, genel anlamıla temel bir gelirden yoksun olma demektir. Bununla birlikte başta eğitim, sağlık, istihdam ve sosyal güvence olmak üzere insanca yaşamak için gerekli olan insani gereksinimlerden ve kapasiteden yoksun olma anlamına da gelmektedir.

Geçim sıkıntısında olan hanelerde erkeğin ücretinin evin geçimi için yetersiz kalması veya işsiz hale gelmesi sonucunda kadının gelirine gereksinim duyulmaktadır. Ancak bu kadınların "bilgi, kültür ve eğitim vasıfları”na karşılık gelen (Swartz, 2011: 267) kültürel sermayelerini, bireyin hem mal varlığına hem de gelirine işaret eden (Jourdain ve Naulin, 2016: 106) ekonomik sermayeye dönüştürebilecek potansiyelleri de bulunmamaktadır. Kadınların eğitim düzeylerinin düşük olması ve kültürel sermayelerinin yetersiz olması onların çoğunlukla vasıfsız işlere yönelmesine neden olabilmektedir. Swartz’ın (2011: 109) belirttiği gibi, "emek piyasasındaki gelir kaynaklarına erişim, eğitim biçimindeki kültürel sermayeye ve ilişki ağları biçimindeki sosyal sermayeye ${ }^{3}$ bağlıdır”. Yoksulluk içinde olan kadınlar yetersiz kültürel sermayeleri nedeniyle ikincil statüdeki gündelikçi piyasasında yerlerini almaktadırlar. Kadınların gündelikçi piyasasına ulaşımları önemli ölçüde tanışıklıkları ve komşuluk-arkadaşlık ilişkileri aracılığıyla gerçekleşmektedir.

Türkiye’de kentte enformel sektörde belli bir ücret karşılığında gündelikçi olarak çalışan kadınların düzenli bir işe ve yeterli bir gelire sahip olmamaları aynı zamanda düşük eğitimli ve vasıfsız işgücü niteliğinde olmaları onları, Suğur ve arkadaşlarının (2010) ifade ettiği gibi, istihdam altında olan ve gelir elde edebilen ancak buna rağmen yoksul olan kişilere karşılık gelen "çalışan yoksullar" kategorisine dahil etmektedir.

3 Sosyal sermaye, "birbiriyle tanışma ve karşılıklı tanımaya dayalı aşağı yukarı kurumsallaştırılmış bir kalıcı ilişkiler ağına bağlı mevcut veya potansiyel kaynaklar bütünü” olarak tanımlanır (Jourdain ve Naulin,2016: 107). Kısaca, “tanışıklıklar ve ilişki ağları” (Swartz, 2011: 110) sosyal sermayenin içeriğidir. 


\section{ARAŞTIRMANIN METODOLOJİSI}

Araştırmanın konusu; gündelikçi olarak ev temizliği işinde çalışan kadınların sosyolojik özelliklerinin Denizli kent örneğinden hareketle ortaya konulmasıdır. Bu araştırmada gündelikçi kadınların sosyo-ekonomik durumlarının, çalışma yaşamlarının, kendi statülerini algılayış biçimlerinin, boş zaman etkinlikleri ve gelecek beklentilerinin kendi bakış açılarından nasıl görüldüğünün ortaya konulması amaçlanmıştır.

$\mathrm{Bu}$ araştırma derinlemesine görüşmelerin yapıldığı, "olgu ve olayların kendi doğal ortamları içinde gerçekçi ve bütüncül bir şekilde ortaya konmasına yönelik nitel bir sürecin izlendiği araştırmadır” (Yıldırım ve Şimşek’den 2005 akt. Gönç-Şavran 2009: 85). Araştırmada veriler on gündelikçi kadınla yapılan bire bir derinlemesine görüşmeler yoluyla toplanmıştır. Görüşmeler gündelikçi kadınlardan izin alınarak ses kayıt cihazına kaydedilmiştir. Her bir görüşme ortalama 35 dakika sürmüş olup, toplam beş saat elli yedi dakikalık ses kaydı alınmıştır. Görüşmeler tamamlandıktan sonra her bir ses kaydı yazıya dökülerek bilgisayar ortamına aktarılmıştır. Araştırmacı ile gündelikçi kadınlar arasında güven ortamı sağlanmış, gündelikçi kadınlar soruları içtenlikle yanıtlamışlardır. Gündelikçi kadınlardan öncelikle bir tanesine ulaşılmış, daha sonra kartopu tekniği kullanılarak diğer dokuz kadına erişim sağlanmıştır. Nitel araştırmada, Yıldırım ve Şimşek'in (2000) belirttiği gibi, üç yöntem öne çıkmaktadır. Bunlar; 1) Betimsel analiz yöntemi, 2) Betimsel ve sistematik analiz yöntemi, 3) Betimsel, sistematik ve veri analizi yöntemidir (akt. Demir, 2009: 312). Bu araştırmada gündelikçi kadınlardan elde edilen veriler betimsel analiz yöntemi kullanılarak analiz edilmiştir. Araştırmacı gündelikçi kadınların ifadelerini olduğu gibi (kendi şiveleriyle/yazım kurallarına bakılmaksızın) aktarmış, gündelikçi kadınların ifadelerinden bir bağlam oluşturarak yorumlarda bulunmuştur. Araştırmada kişisel bilgilerin gizliliği esası gereği gündelikçi kadınların gerçek isimleri gizli tutulmuş, onun yerine takma isimler kullanılmıştır. Araştırma 2018 yılının Mayıs ayında gündelikçi kadınların ev toplantılarında onlarla bir araya gelerek gerçekleştirilmiştir.

\section{ARASTTIRMA BULGULARI}

\subsection{Gündelikçi Kadınların Sosyo-ekonomik Durumlarına İlişkin Bulgular}

Araştırma kapsamında yer alan kadınlar on kişi olup, gündelikçi kadın olarak ev temizliği işinde çalışmaktadır. Ancak kadınlardan üçü gündelikçi olarak ev temizliği dişında başka işle de meşgul olmaktadır. Bu kadınlardan birisi bijutericide, birisi tekstilde, bir diğeri de çocuk bakıcısı olarak çalışmakta; hafta sonları iş geldikçe gündelikçi olarak ev temizliği işine gitmektedirler. Bu ayrıntıyı paylaştıktan sonra, gündelikçi kadınların genel özelliklerini tanıtan aşağıdaki tablodan hareketle sosyo-ekonomik durumlarına ilişkin bulguların değerlendirmesine gitmek yerinde olacaktır. 
Tablo 1: Gündelikçi Kadınları Tanıtıcı Özellikler

\begin{tabular}{|l|l|l|l|l|l|}
\hline $\begin{array}{l}\text { Gündelikçi } \\
\text { Kadının Mahlası }\end{array}$ & Yaşı & $\begin{array}{l}\text { Eğitim } \\
\text { Durumu }\end{array}$ & Doğum Yeri & $\begin{array}{l}\text { Medeni } \\
\text { Durumu }\end{array}$ & Çocuk Sayısı \\
\hline Nergis & 32 & İlkokul Mezunu & Köy & Evli & 2 \\
\hline Çiçek & 34 & İlkokul Mezunu & Köy & Boşanmış & 1 \\
\hline Mine & 40 & İlkokul Mezunu & Köy & Evli & 2 \\
\hline Fulya & 41 & Lise Mezunu & Köy & Boşanmış & 1 \\
\hline Lale & 42 & İlkokul Mezunu & Köy & Boşanmıs & 3 \\
\hline Damla & 44 & İlkokul Mezunu & Köy & Evli & 2 \\
\hline Fidan & 46 & İlkokul Mezunu & Köy & Boşanmış & 2 \\
\hline Sümbül & 52 & İlkokul Mezunu & Köy & Boşanmış & 1 \\
\hline Manolya & 52 & Lise Mezunu & Köy & Evli & 2 \\
\hline Pelin & 53 & İlkokul Terk & Köy & Evli & 2 \\
\hline
\end{tabular}

Gündelikçi kadınların tamamı köy kökenli olup, hepsi evlendikten sonra Denizlìye göç etmişlerdir. Kadınların medeni durumuna bakıldığında yarısının evli, diğer yarısının boşanmış olduğu görülmektedir. Boşanmış kadınların tamamı aldatıldıkları ve şiddet gördükleri için boşandıklarını dile getirmişlerdir. Gündelikçi kadınlar boşandıkları eşleriyle ilgili geçmişte yaşadıklarını göz önüne alarak eşlerini anmak istemediklerini, onları hayatlarından sildiklerini dile getirmişlerdir. Nitekim görüşülen kadınlardan birisi bu durumu şu şekilde ifade etmiştir:

"Hayatımın karanlık bir sayfası onu açmak istemiyorum" (Fulya).

Kadınların tamamı çocuk sahibi olup, ağırlıklı olarak iki çocukludurlar. Gündelikçi kadınların ailelerinin çekirdek aile tipinde ve parçalanmış aile tipinde olduğu görülmektedir. Kadınlar 32-53 yaş aralığında yer alırken; yoğunluklu biçimde 40’lı yaşlarda oldukları dikkati çekmektedir. Kadınların ikisi lise mezunu, birisi ilkokul terk olup, geri kalanları ilkokul mezunudur. Buna göre gündelikçi kadınların düşük eğitim seviyesine sahip olduğu söylenebilir.

Gündelikçi kadınlara eşlerinin eğitim durumları ve meslekleri sorulduğunda, eşinden boşanmış olan kadınlar bu soruları yanıtsız bırakmışlardır. Evli olan kadınlardan birisinin eşi lise mezunu, geriye kalanların eşleri ilkokul mezunudur. Gündelikçi kadınların eşlerinin meslekleri ise genelde düşük vasıflı, düzenli olmayan işlerdir (inşaat işçisi, pazarcı, mobilya işçisi, pide işçisi, tekstil işçisi). Gündelikçi kadınların tamamının annelerinin ve babalarının eğitim durumları ilkokul düzeyindedir. Gündelikçi kadınların eğitim durumlarının düşük olmasında, ailelerinin eğitim düzeyinin düşük olmasının etkisi olduğu söylenebilir. Nitekim görüşmelerde de kadınlar sıklıkla okumak istediklerini ancak köy yerinde kızların okumasına sıcak bakılmadığını, babaların da kızlarını okutma 
taraftarı olmadığını dile getirmişlerdir. Örneğin, görüşülen kadınlardan birisi bu durumu şu şekilde ifade etmektedir:

"Derslerim iyiydi aslında da babam istemedi. Hani köylük yerinde kızlar okumaz mantığı vardı ondan okuyamadım" (Mine).

Gündelikçi kadınların dokuz tanesi Denizli'nin daha çok alt gelir grubundan gelen ailelerin oturduğu Topraklık-Kayalık mahallesinde, bir tanesi Çaybaşı mahallesinde ikamet etmektedir. Kadınların yarısı kirada kalırken, diğer yarısının evlerinin mülkiyeti kendilerine aittir.

Tablo 2: Gündelikçi Kadınların (Bireysel) Aylık Kazançları

\begin{tabular}{|l|l|}
\hline Aylık Kazanç (Bireysel) & Gündelikçi Kadın Sayısı \\
\hline $1600-2000$ TL & 5 \\
\hline $2001-3000$ TL & 3 \\
\hline $3001-4000$ TL & 2 \\
\hline
\end{tabular}

Gündelikçi kadınların gelir durumuna bakıldığında çocuk bakıcılığı işinde, tekstilde ve bijuteride çalışan üç kadın sabit asgari ücret düzeyinde gelir almaktadır. Ancak hafta sonları iş geldikçe gündelikçi olarak ev temizliğine gitmektedirler. Görülen o ki, asgari ücretin ${ }^{4}$ altında geliri olan yoktur. Kadınların çoğunluğu 1600-2000 TL gelir aralığında yer almaktadırlar. Yapılan görüşmelerde evli olan kadınların eşlerinin düzenli bir işi olmadığı anlaşılmıştır. Gündelikçi kadınlar eşleri çalıştığında ise en fazla asgari ücret düzeyinde gelir aldığını söylemişlerdir. Bunu da hesaba katarsak, gündelikçi kadınların dört kişilik bir aile için hesaplanan gıda harcaması ile birlikte giyim, konut (kira, elektrik, su, yakıt), ulaşım, eğitim, sağlık ve benzeri ihtiyaçlar için yapılması zorunlu diğer harcamaların toplam tutarı olan yoksulluk sınırı ve altında olduklarını söyleyebiliriz.

Gündelikçi kadınların kendi bakış açılarından ekonomik durumlarını nasıl gördüğü araştırılmak istenmiş, bu bağlamda onlara "ekonomik durumunuzu nasıl tanımlarsınız?" sorusu yöneltilmiştir. Kadınların sekizi, ekonomik durumunu "orta halli” olarak tanımlarken sadece ikisi "fakir" olarak tanımlamıştır. Kadınların ekonomik olarak kendilerini orta halli görmelerine ilişkin anlatılarında "çalışıyor olma”, "günlük para kazanabilme", "kimseye muhtaç olmadan işini gücünü görebilme", "kendi yağlarıylatuzlarıyla kavrulabilme, "aç değil açıkta değiliz" ifadeleri ön plana çıkmıştır.

Kendilerini yoksul olarak algılayan gündelikçi kadınların anlatılarında "Nasıl yoksul

42018 yılı net asgari ücret tutarı 1603 TL olarak belirlenmiştir. Ayrıntılı bilgi için bkz. www.turkis.org. tr/2018-YILI-ASGARI-UCRET-ACIKLANDI-d11676

5 Türk-İş 2018 yılı Nisan Ayının yoksulluk sınırını 5.473,38 TL olarak açıklamıştır. Ayrıntılı bilgi için bkz. http://www.turkis.org.tr/NISAN-2018-ACLIK-ve-YOKSULLUK-SINIRI-d31736 
olmayalım, öbür türlü belediyeye gider miydik? Belediye verir miydi benim oğlana burs?” (Sümbül), "Ev kira. Çocuğun giyimiydi, okuluydu, hep para. Abacım söyle sen, ne gezsin fakir adamda para? Para yetmiyor, ondan sosyal yardımlaşmaya başvuruyoruz, yardım kömürüydü falan. Fakir olmasak zaten başvurmazdik ihtiyacı olan alsın derdik ama işte abacım bizde fakir olduğumuzdan mecbursun" (Nergis) şeklinde ifadelerle karşılaşılmıştır. Görüldügü üzere kadınlar anlatılarında, sosyal yardımlaşmadan yardım aldıkları, çocuklarına belediyeden burs aldıkları için yoksul olduklarını dile getirmişlerdir. Burada yoksulluk kriteri, yardıma muhtaç olduklarının bir kurum tarafından belgelendirilmesidir. Sosyal yardımlaşma ve belediye destekleri kendilerini "damgalanmış" olarak algılamalarına neden olmaktadır. Bu damgaya sahip olanlar kendilerini diğer kadınlardan farklı görmektedirler. Kadınların bu davranış biçimleri, yoksulu toplumsal bir tip olarak ele alan Simmel'in ifadesiyle paralellik göstermektedir. Simmel'e göre "[yoksula] yardım edildiği andır ki... onlar yoksulluk tarafından karakterize edilen bir grubun parçası halini alırlar" (akt. Coser, 2008: 172).

Gündelikçi kadınlara "yoksul kimdir?” sorusu yöneltildiğinde, kendilerini yoksul olarak tanımlayanlar "yoksul biziz" (Sümbül), "durumu benim gibiyse yoksuldur" (Nergis) ifadelerinde bulunmuşlardır. Kendini yoksul olarak görmeyen kadınlar sıklıkla anlatılarında, "yoksul çalışmayan insandır" (Mine), "işi gücü olmayana denir" (Çiçek), "bir kişi çalışmıyorsa bilesin o yoksuldur. Mesela bir insan mutlaka çalışmalı yoksa düşkün hale düşer" (Fidan) şeklinde ifadelerde bulunmuşlardır. Yoksulu "karnını zor doyuran, ekmeği zor bulan kişi” (Lale), "canı isteyip de bulamayan, almak isteyip de alamayan" (Pelin) olarak niteleyen de olmuştur. “Zengin kime denir?” sorusu sorulduğunda ise sıklıkla kendi işverenlerini örnek göstermişlerdir. Görüşülen kadınlardan birisi bu durumu şöyle dile getirmiştir: "İşverene zengin denir. Çünkü işveren bir sürü insana ekmek kapısıdır" (Mine). Kimi kadınlar da anlatılarında "bir eli yağda bir eli balda olan, kazancından fazla yiyen" (Sümbül), "malı mülkü çok abartı olan" (Damla) ifadeleriyle zengini tanımlama yoluna gitmişlerdir.

Ortaya şöyle bir tablo çıkmaktadır: Gündelikçi kadınlar çoğunlukla kendilerini orta halli olarak tanımlamaktadır. Bu algılarının oluşmasında, gündelikçi kadınların çalışma ediminde bulunmaları ve çalıştıkları gün sayısının fazla olması dolayısıyla gelirlerinin de fazlalaşması etkili olmaktadır. Gündelikçi kadınların kimseye muhtaç olmadan yaşamlarını sürdürmeleri ve istediklerini sınırlı da olsa alabilmeleri bu algılarını şekillendirmektedir. Gündelikçi kadınların çoğunluğu çalışan yoksul olarak tanımlanabilecekken, kendi pencerelerinden baktıklarında kendilerini yoksul olarak görmedikleri söylenebilir. Kendilerini yoksul olarak görenler ise, aylık çalıştıkları gün sayısı az olanlar, dolayısıyla gelirleri de az olanlardır. Bunlar yaşamlarını sürdürebilmek için değişik kanallardan yardım almaktadırlar. Gündelikçi kadınların zenginlik algılarına bakıldığında ise onların çoğunlukla işi veren kişiyi, yani orta sınıf işverenini, kendisini çalıştırıp yoksul olmaktan kurtardığı için zengin olarak algıladıkları görülmektedir. Öyle ki, maddi imkanları sınırlı olduğu ve ellerinde olanla yetinebilmeye çalıştıkları için artı değere sahip olanı zengin statüsünde değerlendirmektedirler. 


\section{2. Çalışma Yaşamlarına İlișkin Bulgular}

Gündelikçi kadınlara çalışmaya başlama öyküsü sorulmuş, tamamı çocukluktan beri çalıştıklarını dile getirmişlerdir. Kadınların hepsi köy kökenli olduğundan ve kırsalda da çocukların çalışması doğal karşılandığından, erken yaşlardan itibaren ev işlerinde, tarla/ bahçe işlerinde aileye yardımcı olmak şeklinde çalışma etkinliğinde yerlerini almışlardır. İlkokulu bitirdikten sonra tekstilde çocuk işçi olarak çalışmışlardır. Hepsinin ortak özelliği, temizlik işine başlamadan öncede tekstil işinde çalışıyor olmalarıdır. Gündelikçi kadınların temizlik işine başlamadan önceki iş deneyimleri tekstilde aynı paydada birleşirken, tekstil haricinde evde dikiş diken, mermerde, halı dokumacılığında, pazarda çalışan kadınlara da rastlanmıştır.

Gündelikçi kadınlara çalışmaya başlama nedenleri sorulduğunda, kadınlar çoğunlukla "geçim derdi/maddi sıkıntı" nedeniyle çalışma hayatına atıldıklarını dile getirmişlerdir. Ailesi istediği için, çocuklarını okutmak için, muhtaç olmamak için, okul okumadığ i için çalışmaya başladıklarını belirtenler de olmuştur. Kadınların çalışmaya başlamaları daha çok ekonomik nedenlidir. İçinde bulundukları maddi imkansızlıklar, onlara çalışmaktan başka bir seçenek sunmamıştır. Görüşme yapılan kadınların ifadelerinde de bu durumu görmek mümkündür:

"Hiçbir şeyimiz yok. Sadece iki pamuk yatak, bir üstümüz başımız biraz, bir tane de ortası delik kilim. O tarafa baktım bu tarafa baktım yani geçim zor. Eşim çalışıyor inşaatta. Bir dediler, ev sahibimiz vardı, kızım dedi, ev temizliğine gider misin dedi, şurada bir yer var dedi. Tamam giderim dedim" (Pelin).

"Tek aylıkla yetmiyor çünkü iki tane çocuğum okula gidiyor onların ihtiyaçları çok. Ev kirası, yemen içmen hani işte oradan giderin fazla oluyor. Ayın ucunu denk getiremiyorsun. Ondan ben çalışmak istedim" (Nergis).

Kadınlar bir geçim stratejisi olarak ev temizliği işinde çalışmaya başlamışlardır. Gündelikçi kadınlara eşlerinin çalışma kararlarına nasıl tepki verdiği sorulmuştur. Kadınlar bu konuda ikiye ayrılmıştır. Kimisinin eşi çalışmasına olumlu yaklaşmış; kimisinin eşi çalışmasını başta olumlamamıştır. Çalışma konusunda eşlerinden başlarda destek görmeyen kadınlar eşleriyle tartışmışlar buna rağmen çalışma konusundaki kararlılıklarını sürdürmüşlerdir. Kadınların kararlı olması ve ailenin yaşadığı maddi imkansızlıklar karşısında eşler bu konuda 1srarcı olamamışlardır. Nitekim gündelikçi kadınlardan biri bu durumu aşağıdaki gibi ifade etmiştir:

"İlk başlarda desteklemedi. Çalışmayacaksın dedi. Çocuğa bakacaksın dedi. Bir süre çalışmadım zaten ama sonra ev temizliğinde çalışmaya kendim karar verdim. Baya bir tartışma oldu ama sonrasında kabul etti, benim çalışacağımı ne kadar kararlı olduğumu anladı. E kendi parası da yetmez olunca mecbur kaldı kabul etmeye" (Mine).

Gündelikçi kadınlara “ev temizliği işini nasıl buldunuz?” sorusu sorulmuştur. Kadınlardan 
birisi ev sahibi aracılığıyla, birisi de komşusu aracılığıyla işi bulmuştur. Bir diğer kadın ise önce cami temizliğine gitmeye başlamış oradan ev temizliği işine kendi çabasıyla geçmiştir. Bu kişi aynı zamanda geriye kalan kadınları ev temizliği işine yönlendirmiştir. Görüştüğümüz kadınlar bu kişiyi lider olarak kabul etmekteler ve ona kendi aralarında "başkan" olarak hitap etmektedirler. "Başkan” olarak hitap edilen kişi gündelikçi piyasasında kendini kabul ettirmiş ve yaptığı temizlik işinden işverenleri memnun kalmıştır. Öyle ki, işverenleri ev temizliğine o kişinin gelmesini talep etmekte ve başkalarına da tavsiye etmektedirler. Bu kişi haftanın hemen hemen altı günü çalışmakta ve boş vakti olmadığı için kendisine iş gelmesi durumunda diğer gündelikçi arkadaşlarını işe göndermektedir. "Başkan" kabul edilen kişi arkadaşlarını işe yönlendirmesi karşılı̆̆ında hiçbir maddi kazanç sağlamamakta, korumacı ve dayanışmacı kimliği ile hareket etmekte ve bu özelliği sayesinde diğer gündelikçi kadınlar tarafından saygı görmektedir. Gündelikçi kadınların tabiriyle "kader ortaklığı" giderek birlikte çalışan, birlikte eğlenen hatta aynı semtte oturmaya başlayan bir pozisyona bürünür.

Gündelikçi kadınların kaç yıldır ev temizliği işi yaptığına bakıldığında ise, içlerinde bu işe yeni başlayanlara rastlanmamıştır. Kadınların gündelikçi piyasasında konumlanışları 3 yıl ila 25 yıl arasında değişkenlik gösterirken, çoğunluğu ev temizliği işinde 5 yıllık deneyime sahiptir.

Gündelikçi kadınların çalışma koşullarına bakıldığında, kadınlar bir eve günlük 140 TLye temizliğe gitmekte, yarım gün temizliğe gittiklerinde ise 70 TL almaktadırlar. Gündelikçi kadınlar evlere çoğunlukla yarım günlügüne gitmekte, bir gün içinde yarım günlük iki eve gittikleri de olmaktadır. Tam gün gittikleri evler ise daha sınırlı kalmaktadır. Gittikleri evler haftada bir, iki haftada bir, ayda bir şeklinde dönmektedir. Sadece hafta sonraları gündeliğe gidebilen üç kadının çalıştıkları gün sayısı sınırlıdır (haftada bir gün). Diğer yedi kadın gittikleri ev sayısı hakkında kesin bir sayı vermemektedirler. Çünkü her hafta bu sayı gelen ek gündelik işine göre değişkenlik göstermektedir. Yedi kadından ikisi çoğunlukla haftada beş-altı gün çalıştıklarını, kalanlar ise haftanın üç günü çalışabildiklerini ancak ek gündelik işi geldiğinde haftada dört-beş gün de çalışabildiklerini ifade etmişlerdir. Bazen haftada iki gün çalıştığını belirtenler de olmuştur. Kadınlar bayram önünde her gün çalışma imkanı bulabildiklerini, bu nedenle bayramların gelmesini iple çektiklerini dile getirmişlerdir.

"Haftada beş gün diyelim altı gün. Düzenli gittiğimde var, on beş günde, ayda bir gittiğimde var. Kaç işveren şu an sayısını bir şey diyemeyeceğim, hiç belli olmuyor" (Mine).

"Bazen haftada dört-beş gün ful olduğumuz oluyor, bazen iki gün olduğumuz oluyor yani öyle. Şu anda sabit gittiğim üç tane yerim var onlarda yarım gün. Yalnız ondan sonra ek iş gelirse, mesela bugün ek iş geldi oraya gittim. Öyle değerlendiriyoruz yani yarım günlerimizi de" (Lale).

Araştırmacı tarafından ekip başı olarak adlandırılan, kadınların kendi aralarında ise 
"başkan" olarak hitap ettiği gündelikçi kadın kendisine ekstra iş geldiğinde diğer kadınları gündeliğe göndermektedir. Bazen bir eve iki kişi gittikleri de olmaktadır. Kadınlar aralarında bir iletişim ağı kurmuşlardır. Gündelik iş çıktığında kim müsaitse, kimin o hafta paraya daha çok ihtiyacı varsa öncelikle o gündelikçi kadın gönderilmektedir. Görüşülen kadınlar bu durumu şu şekilde ifade etmektedirler:

"Başkan yani Mine aban să̆ olsun. Benim temizlik işine başlamama o vesile oldu abacım. Hafta içi çocuk bakıcılı̆̆ı yaptığımdan ötürü hafta sonları temizlik işini o ayarlayıveriyor. Bazen onunla ikimiz birlikte aynı evi de temizlemeye gittiğimiz oluyor. Şimdi hakkını yiyemem yani să̆ olsun" (Nergis).

"İki haftadır ek işe gidiyorum. Bugün de gittim mesela. Mine’den Allah razı olsun. Şu sıra para kalmadı. Kızım da üniversitede okuyor. Ona para göndermem gerekti. Mine kendine gelen işlere beni gönderdi mesela o yüzden çok iyi oldu” (Lale).

Aynı sosyo-ekonomik statüye sahip olan gündelikçi kadınlar arasında yatay dayanışma ilişkileri bulunduğu söylenebilir. Bu tabloya göre gündelikçi kadınların aralarındaki bu ilişki ağları onların sosyal sermayeyi yatay olarak kullandığının bir işaretidir. Gündelikçi kadınların sosyal sermayeyi yatay kullanımı, Suğur ve arkadaşlarının (2010: 103) ifade ettiği gibi, onların enformel sektör içerisinde tutunmasını sağlamaktadır.

Gündelikçi kadınların içinde bulundukları maddi imkansızlıklar onların ev temizliği dışında binaların merdivenlerini yıkama, bankaların camını silme, inşaatların temizliğini yapma şeklinde ek işlere yönelmesine neden olmaktadır. Kadınlar arasında inşaat temizliği işi kolektif olarak yapılmaktadır. Ekip başı olan kadın, kendisine inşaat temizleme işi gelince diğer kadınları örgütlemekte hep bir elden işe koyulmaktadırlar.

Gündelikçi kadınlar işverenlerinin çoğunlukla öğretmen ve bankacı olduğunu dile getirmektedir. Gündelikçi kadınların işverenlerinin orta sınıfa mensup aileler olduğu söylenebilir. Gündelikçi kadınlar ile işverenleri arasındaki ilişkiye bakıldığında, formel anlamdaki ya da fabrika ortamındaki işçi-işveren ilişkisinden farklı olduğu görülmektedir. Ev hizmetliliğinde ilk başlarda resmiyete dayanan ilişkiler zamanla yerini samimiyete, aileden birisi gibi olmaya bırakmaktadır (Suğur vd., 2010: 51). Aileden birisi gibi olma olgusu maternalist bir ilişkinin varlığına işaret etmektedir. Maternalizm, "işçi-işveren ilişkisinin aile ilişkisi imişçesine adlandırılması ve buradaki iktidarın görünmez kılınması" (Bora, 2014: 168) olarak tarif edilebilir. Nitekim görüşmelerde de, gündelikçi kadınlar orta sınıf işverenleri ile ilişkilerini anne-evlat/abla-kardeş ilişkisi gibi nitelemişler, kendilerine aileden biri gibi davranıldığını dile getirmişlerdir. Ne var ki, özünde sınıf temelli olan bu istihdam ilişkisinin sınıfsal özelliğinin suni akrabalık ilişkisi ile gizlendiği söylenebilir.

"Sen bizim ailedensin diyorlar, öyle kendini dışarılama diyorlar. Mesela kendilerine bir şey alsalar bene de alıyorlar öyle ayrımcilik şeycilik yok yani. Mesela hanımım bene Nergis diyor bende ona Fatma hanım diyorum hani onlar biraz daha benim şeyim ya saygı şeysi” (Nergis). 
Maternalist ilişkiler sayesinde işverenler gündelikçi kadınlar üzerinde daha çok söz sahibi olabilmekte, yapılması konusunda anlaştıkları işler dışında ekstradan işler (ütü yaptırmak vb.) yaptırtabilmektedirler. Görüşmelerde gündelikçi kadınlardan biri şöyle ifade etmektedir: "Evine gittiğim bir abla var. İş biter, yok ütü var, yok şu dolabın içi silincek. Aslında onlar ekstraya giriyor. Aslında iyide birisi, iş aralarında kahvemizi içeriz, sohbetimizi ederiz. Mesela bayramlarda, yılbaşlarında ya da öylesine hediyeler alır. Ondan sesimi de çıkaramam, kıramam, yapıveririm bende" (Damla). Bu anlatıya göre, işverenlerin bu durumu ücret dışında hediyeler vererek olağanlaştırmaya, karşı taraf için katlanılabilir kılmaya çalıştığı söylenebilir.

Diğer yandan maternalizm gündelikçi kadınlar için "toplumsal onay, destek ve duygusal yakınlık sağladığı için ezilmeyi hafifletici bir işlev” (Bora, 1014: 169) taşıyabilmektedir.

"İşverenlerim bizim işçimiz onu hani ezelim diye hiç uğraşmıyorlar. Mesela bir şey yapılacaksa yapar misın diyorlar, hani işin bitince yapar mısın diyorlar. Hani seni ezme durumu gibi yok"(Nergis).

İşverenlerle gündelikçi kadınlar arasındaki maternalist ilişkiler gündelikçi kadınların temizlik işini yaparken işverenin evini kendi evi gibi görebilmesine neden olmaktadır. Gündelikçi kadınların işverenleriyle geliştirdikleri karşılıklı güven duygusu ve aileden biri gibi görülme hissi gündelikçi kadınlarda çalışanına sahip çıkan işveren imgesi oluşturmaktadır. Buna karşılık gündelikçi kadınlar işverenlerinin evini sahiplendiklerini ve işverenin evinde kendi evindeymişçesine rahat hareket etme olanağına kavuşabildiklerini dile getirmektedirler:

"Girdiğim bütün evlerde bir aile gibi oluyoruz onlar bana sahip çıkıyor ben onların evlerine sahip çıkıyorum bir güven oluyor ya insanlarda öyle bir ilişkimiz var. Evlat ilişkisi gibi diyelim, yani hiç temizlikçi gibi görmezler gittiğim ev sahipleri. Bugün mesela bir teyzeme gittim ben, girgır şamata var mı böyle bir şey müzik çalıyor mesela oynuyoruz" (Fulya).

"Öyle yani kızı gibi görüyor, kardeşi gibi görüyor, hani gittiğimde sıkılma rahat ol evin gibi istediğini ye iç diyorlar şükür” (Lale)

Gündelikçi kadınlar sıklıkla işverenleri hakkında olumlu ifadelerde bulunmuş, işverenlerinin kendilerini aileden biri gibi görmeleri gündelikçi kadınların işlerini severek yapmalarını sağlamıştır. Ancak işverenlerin tutum ve davranışlarından rahatsız olan, işinin en sevmediği yönünün bu tür davranışlara maruz kalmak olduğunu düşünen ve bu konuda serzenişte bulunan kadınlar da olmuştur.

"Kimisi temizlikçi olunca aşağılıyor o kadar aşağılanıyorsun ki sanki köleymişsin gibi o anda parmağında elinde oynatıyor seni. Kimisi yemek bile yedirmiyor, konuşmaya bile tenezzül etmez" (Çiçek). 
Gündelikçi kadınlar kimi zamanlarda aşağılanmak, küçük görülmek, giyimi kuşamıyla dalga geçilmek vb. durumlarla karşılaşabildiklerini bu şekilde kendisini dışlayıcı tavır takınan işverenler olduğunda o işi bıraktıklarını dile getirmişlerdir. Bunun yanı sıra gündelikçi kadınların çoğunluğu temizlik yaparken işverenlerin onların etraflarında dolaşmasından ve onlara işlerini öğretmeye çalışmasından şikayetçi olmuş, işverenlerinin ekstradan işler buyurmasından oldukça rahatsız olduklarını ifade etmişlerdir. İşverenlerin gündelikçi kadınlara ekstradan iş buyurmaları gündelikçilerin yaptıkları işin tanımının belirsiz olduğuna işaret etmektedir. Başlangıçta tarafların sözlü olarak yaptığı anlaşma ile işin sınırları çizilmiş olsa da, işverenle gündelikçi kadın arasında oluşturulan maternalist ilişkiler sözlü biçimde yapılan anlaşmadan uzaklaşılmasına gündelikçi kadınların yaptıkları işlerin belirsizleşmesine neden olabilmektedir. Nitekim görüşmelerde gündelikçi kadınlardan biri bu durumu şu şekilde dile getirmiştir:

"Mesela bir şey yapıyorsun başka şeyde yaptırmaya çalışıyorlar. Mesela şunu yapar mısın eder misin diyorlar mesela baştan şu şu olacak diyorlar ama sonra çoğaltıyorlar" (Manolya).

Gündelikçi kadınlar iş memnuniyetlerini dile getirirken, ücret konusuna da değinmişlerdir. Ücret artışlarını yıldan yıla yaptıklarını ve ücretlerde 10 ila 15 Türk lirası arasında bir artışa gittiklerini söylemişlerdir. Ücret artışlarında televizyondaki memur maaşlarına zam haberleri, enflasyon haberleri gibi haberler ile mevcut gündelikçi piyasasındaki gelişmeler belirleyici olmaktadır. Bu piyasada ücret artışları kulaktan kulağa duyulmakta, her gündelikçi çevre bu artışa ayak uydurmaktadır.

Nitekim görüşme yapılan kadınlar ücret artışı yapacakları zaman birisinin evinde toplandıklarını, ücret artışını gerek gündelikçi piyasasının durumuna bakarak gerekse televizyondan duydukları zam haberlerini referans alarak belli müzakereler sonucunda karar verdiklerini belirtmişlerdir. Ne var ki, gündelikçi kadınlar kimi işverenlerin bu artışa sıcak bakmadığını ifade etmişler, özellikle yol parasını kendilerinin ödediğini, bu durumun kendileri için haksızlık olduğunu dile getirmişlerdir. Manolya'nın anlatısında bu durumu görmek mümkündür: "Artış istedin mi daha indirmeye çalışıyorlar, neden bilmiyorum. Hem bir de otobüs parasını kendi cebimden veriyorum. Öyle ekstradan vermiyorlar, bu haksızlik oluyor yani gerçekten"

Gündelikçi kadınların önem verdiği bir diğer husus ta kahvaltı ve öğlen yemekleridir. Onlar yemek konusunda çok hassas olduklarını ısrarla vurgulamışlardır. Bu bağlamda gündelikçi kadınlara kahvaltı hazırlanması ve kendilerine öğlen yemeğinin verilmesi onların yaptıkları işten duydukları memnuniyet düzeyini artırmaktadır.

Gündelikçi kadınların sıklıkla söz ettikleri konulardan birisi de kullandıkları kimyasal ürünlerdir. Özellikle çamaşır suyu gibi ürünlerin sağlıklarını olumsuz etkilediklerini, bu ürünleri solumanın nefes darlığına neden olduğunu, öksürük nöbetleri geçirdiklerini, kullanılan kimyasalların karıştırıldığında çok tehlikeli olabildiğini bu nedenle zehirlendiklerini dile getirenler de olmuştur. Evi temizlerken koltukları, dolapları 
tek başlarına çektikleri için bel ve sırt ağrısı yaşadıklarını, sürekli eğilmekten duruş bozuklukları meydana geldiğini, sürekli hareket halinde ve ayakta olmaktan diz ağrıları, eklem ağrıları çektiklerini belirtmişlerdir.

Gündelikçi kadınların üzerinde durduğu konulardan bir diğeri de sigorta meselesidir. Gündelikçi kadınlardan sadece beş tanesi sigortalıdır. Bunlardan birisi bujitericide de çalıştığı için sigortası oradan yatırılmaktadır. Bir diğeri de gündelikçiliğin dışında bir evde çocuk bakıcısı olarak çalıştığı için oradaki işverenleri tarafından sigortası yatırılmaktadır. Diğer üç kadınsa "Ek-5 Tarım Sigortası" olarak adlandırılan isteğe bağlı sigorta kapsamındadır. Bu kadınların sigorta primleri ev temizliğine gittikleri işverenleri tarafından ödenmemektedir. Onlar sigorta primlerini kendileri ödemektedirler. Nitekim, görüşülen gündelikçi kadınlardan biri şu şekilde dile getirmiştir:

"İlk sigortaya başlayışım tekstilde çalışaraktan başladım. İște on bir yıldır tarım sigortası kendim yatırdım, oradan günümü doldurdum. Tarımdan emekli olacağım. Bu, devletin ev hanımlarını dahil ettiği bir sigorta, sağlık yardımı hem sağlıktan yararlanıyorsun hem de sigorta gününü dolduruyorsun, bir de erken emekli olma şansin var ek beş tarımdan. Mesela ben üç yıl oldum dolduralı, yaş bekliyorum” (Mine).

Araştırma kapsamındaki kadınların yarısı sigortasız çalışmaktadır. Sigortaya kayıtlı olanlar ise ev temizliği işi üzerinden kayıtlı değillerdir. Bu durum gündelikçi piyasasının enformel nitelikte olduğunun bir göstergesidir. Ancak gündelikçi kadınlar gündelikçi piyasasının enformel koşullarına rağmen bu piyasada iş sahibi olmaktan memnun gözükmektedirler. Sigortasız çalışıyor olmak, onlar için bir dezavantaj olsa da onların sigortasız çalışmayı kabullenmiş gözüktüğü söylenebilir. Gündelikçi kadınlar için öncelikli olan geçimini sağlayabildikleri bir işe sahip olmak ve bu işten asgari ücretten daha fazla para kazanabilmektir. Ne var ki, hepsi sigortalı çalışmanın öneminin farkındadırlar. Onlar sigortalı çalışmanın insanın garantisi/gelecek garantisi olduğunu, emeklilikte çalışmadan elde edilebilecek bir gelir olduğunu söylemekteler ancak arkasından hemen eklemektedirler:

"Sigortalı olmak iyi güzel hoșta sigorta primlerini hangi parayla ödeyeceksin ablacım, kim ödeyecek?” (Manolya).

\subsection{Gündelikçi Kadınların Kendi Statülerini Algılayıș Biçimleri}

Gündelikçi kadınların çoğunluğu tüm olumsuzluklarına rağmen işlerini sevdiklerini, yaptıkları ev temizliği işini bir meslek olarak gördüklerini ifade etmektedirler. Onlar yaptıkları işi önemsiyor gözükmektedir. Gündelikçi kadınlar temizlik işi sayesinde geçimlerini sağladıklarının bilincinde olup yaptıkları işe saygı duymaktadırlar. Görüşülen gündelikçi kadınlardan biri temizlik işini şu şekilde gördügünü anlatmaktadır: "Mesleğim diyorum ben tertemiz mesleğim alnımın akıyla paramı kazanıyorum diyorum çünkü her çeşit telden para kazanan insanlar var namusumuzla para kazanıyoruz insanlar var alnımızın teri derler ya çok şükür, bu işe saygıyla eğilinmeli” (Fulya). 
Ev temizliği işini meslek olarak görmeyen gündelikçi kadınlar da bulunmaktadır. $\mathrm{Bu}$ kadınlar ev temizliği işinin düşük statülü ve vasıf gerektirmeyen bir iş olduğunu, eğitim gerektiren ve belli statüye sahip olan öğretmenlik ve hemşirelik meslekleri gibi olmadığını, sıradan bir iş olduğunu belirtmektedirler. Nitekim, görüşmelerde kadınlardan biri bu durumu şöyle dile getirmektedir: "Ben bu ev işini meslek olarak görmüyorum. Mesela bir öğretmen gibi ne bileyim bir hemşire gibi şey yapmıyorum. Yani normal bir iş gibi görüyorum” (Fidan).

Gündelikçi kadınların tamamı ev temizliği işine başlamadan önce tekstilde çalışmışlardır. Bu bağlamda şu anki işlerini sıklıkla tekstil işiyle kıyaslamışlardır. Onlara göre gündelikçi olarak ev temizliği işinde çalışmak tekstilde çalışmaya göre daha avantajlıdır ve daha az yıpratıcıdır. Gündelikçi kadınlar tekstilde en fazla asgari ücret düzeyinde para alabildiklerini oysa temizlik işinde asgari ücretten daha fazla para aldıklarını vurgulamışlardır. Ayrıca gündelikçi kadınlar tekstildeki gibi vardiya sorunlarının olmadığını, kendilerine göre iş gününü ve saatini belirlediklerini, işleri çıktığında temizliğe gitmeme durumlarının olduğunu belirtmişlerdir.

Gündelikçi kadınların kendi statülerini nasıl gördükleri araştırılmak istenmiştir. $\mathrm{Bu}$ bağlamda gündelikçi kadınlara kendilerini işçi olarak görüp görmedikleri sorulmuştur. Kadınların tamamı kendilerini işçi olarak gördüklerini dile getirmişlerdir. Gündelikçi kadınlar emeğiyle geçinen insanlar oldukları, bir işte çalışıyor oldukları ve işveren tarafından çalıştırıldıkları için işçi olduklarını vurgulamışlardır.

"Ablam ya işçiyiz sonuçta parasını veriyor, temizliğini yaptırıyor, gönderiyor sonra. Mesela bir memur öyle değil gidiyor halbusem hep aynı şeyi yapıyor mesela oturuyor akşama kadar. Ama tamam o kafa olarak çalışıyor ama biz beden olarak çalışıyoruz. Bence beden gücü daha önemli” (Çiçek).

"Evet işçiyim. Bu bir iş, ev temizliği yapmakta bizim için bir iş sonuçta. O eve gidiyorsun dip köşe o evi temizliyorsun onun için” (Mine).

Gündelikçi kadınlara "size göre çalışmanın anlamı nedir?” sorusu da yöneltilmiştir. Gündelikçi kadınlar çalışmanın öncelikle bir zorunluluk olduğunu ifade etmişlerdir. Bu bağlamda sıklıkla yaşamak için, geçimini sağlamak için çalışmak zorundasın söylemini kullanmışlardır. Çalışmayı bir zorunluluk olarak görmelerine rağmen onu eziyet olarak algılamamaktadırlar. Çalışmayı tarif ederken çalışmanın özgürlük olduğunu, insana özgüven verdiğini, kendi başına ayakta durmak, para kazanmak, istediğini alabilmek, dinç ve sağlıklı olmak, yeni insanlarla iletişim kurmak olduğunu dile getirmişlerdir.

Gündelikçi kadınlara "toplumun ev temizliğine giden kadınlara nasıl bir yaklaşımı vardır?” sorusu sorulmuştur. Kadınların hepsi toplumda gündelikçi kadınların değerinin bilinmediği konusunda hemfikir olmuşlardır. Kadınlar sıklıkla toplumdakilerin kendilerini küçümsediğini, aşağı gördüklerini dile getirmişler, toplumda hak ettikleri bir konumda olmadıklarını vurgulamışlardır. Hepsinin ortak temennisi kendilerine toplum 
tarafından saygı duyulması ve değer verilmesi olmuştur.

"Yok bilinmiyor. Basit görüyorlar. Mesela bir öğretmen gibi bir memur gibi görülmüyor yani basit görüyorlar. Ama biz herkesin ütüsünü yapıyoruz, herkesin evini temizliyoruz, herkesin pisliğini temizliyoruz mesela tuvaletlerini temizliyoruz her şeysini yapıyoruz ama değerimiz bilinmiyor" (Manolya).

"Hiçte bilinmiyor. Kimileri aşağıda görüyor kimileri küçümsüyor. Kendilerini yukarda gören insanlar bizleri küçümsüyorlar” (Fulya).

"Temizlikçiyi şey gözünden bakıyorlar aaa bu temizliğe gidiyor. Alçaktan bakıyorlar” (Pelin).

Gündelikçi kadınlara "gündeliğe giden kadınların en önemli sorunu nedir?” sorusu yöneltilmiştir. Onlara göre gündelikçi kadınların en önemli sorunu sigortası/güvencesiz çalışmaktır. Ayrıca kendilerine fazladan iş buyurulmasının önemli bir sorun olduğunu vurgulamışlar, bu konuda serzenişlerini de dile getirmişlerdir. Başka evlerin işlerini gördükleri için kendi evlerinin işini yeterince görememeyi, ev işlerini gece yapmak zorunda kalmalarını sorun olarak dile getirenler olurken, emeklerinin karşılığının verilmemesinin önemli bir sorun olduğunu ifade edenlerde olmuştur.

\subsection{Gündelikçi Kadınların Boş Zaman Etkinlikleri ve Gelecek Beklentileri}

Gündelikçi kadınlar boş zamanlarında çoğunlukla ev toplantıları yapmaktadırlar. Haftada bir akşam birisinin evinde toplanmakta, imece olarak yaptıkları pastalarıbörekleri yemekte ve müzik çalıp oyunlar oynamaktadırlar. Kendi tabirleriyle müzikli altın(sız) günü yapmaktadırlar. Onlar arkadaş toplantılarında bir araya gelerek bir haftanın yorgunluğunu ve stresini attıklarını dile getirmektedirler. Gündelikçi kadınlar ve çocukları bazen de piknik yapmak için mesirelik alanlara gitmektedirler. Sınırlıda olsa belediyenin düzenlemiş olduğu ücretsiz şehir tiyatrosu oyunlarına ve konserlere gittiklerini dile getirmektedirler. Gündelikçi kadınların boş zamanlarını değerlendirme biçimleri onların aralarında güçlü bir bağın ve grup ruhunun olduğunun bir göstergesi olarak yorumlanabilir.

Gündelikçi kadınların televizyonda seyrettikleri programlara bakıldığında çoğunluğu Hint dizilerine ve Survivor'a baktıklarını belirtmişlerdir. Ara sırada olsa haberleri seyrettiğini belirtenler de olmuştur. Gündelikçi kadınların müzik tercihleri ise genellikle arabesk müzikten yanadır. Sıklıkla arabesk müzik dinlediklerini, bunun yanı sıra Ankara havası ve hareketli pop dinlemekten de zevk aldıklarını dile getirmişlerdir.

Gündelikçi kadınların gelecek beklentileri genellikle çocukları ile ilgili olup kendileriyle beklentileri sınırlı kalmaktadır. Onların öncelikli beklentileri çocuklarının okuması ve mesleklerini eline alıp özellikle de memur olmalarıdır. Gündelikçi kadınlar çocuklarının okumasını kendileri gibi "elin kirini” temizlememesi için, hayatlarını kurtarmaları için 
istemektedirler. Onlar bir yandan kendi çocuklarının okumasını temenni ederken, diğer yandan sıklıkla kendi okul özlemlerini dile getirmektedirler.

"Ben kendimde okumayı çok isterdim ama olmadı abam. Ondan çocuklarım çok okusun, hayatlarını kurtarsın hani benim gibi elin temizliklerinde kirinde yapmasınlar, okusunlar. Ben bunu bekliyorum abacım" (Nergis).

Gündelikçi kadınların çocuklarıyla ilgili beklentilerinden sonra gelen beklentileri ise genelde evle ilgili ve sigortayla ilgilidir. Gündelikçi kadınlardan kirada kalanlar ev sahibi olmayı beklerken, sigortasız olanlar da günün birinde sigortalı olup sigortadan emekli olmayı umut etmektedirler.

\section{SONUÇ}

Kadınların gündelikçi olarak ev temizliği işinde çalışması kentsel enformel istihdam biçimlerinden biridir. Gündelikçilik düşük statülü ve vasıf gerektirmeyen bir iş olarak eğitimsiz ve vasıfsız kadın işgücünün yöneldiği önemli bir istihdam kapısı haline gelmektedir. Gündelikçiliğin yasal zeminde tanımlanmadığı dolayısıyla belirli bir iş tanımının ve iş güvencesinin olmadığı ortaya çıkmaktadır. Gündelikçilikte işçi-işveren ilişkisi, formel anlamdaki işçi-işveren ilişkisinden farklı bir görünüm sergilemektedir. Gündelikçi kadınla işvereni arasında ortaya çıkan maternalist ilişkinin, gündelikçiliğin kendine özgü çalışma ilişkilerini doğurduğu anlaşılmaktadır. Maternalist ilişkiler, gündelikçi kadınların kendilerini aileden biri gibi hissetmelerine neden olurken, işverenler bu ilişkiler sayesinde gündelikçi kadınlar üzerinde daha fazla denetim kurabilmektedir. Diğer yandan maternalist ilişkilerin iş tanımının belirsizleşmesine neden olduğu sonucu ortaya çıkmaktadır.

Köyden kente göç etmiş ailelerin, kente uyum sağlamalarına olanak tanıyan tampon mekanizmalardan biri olan hemşehrilik ağlarının, bu araştırma kapsamında bir etkisinin olmadığı ortaya çıkmaktadır. Araştırma kapsamındaki gündelikçi kadınların tamamı köy kökenli olup, köyden kente göç etmiş bu gündelikçi kadınların kendi aralarında kurdukları arkadaşlık ilişkilerinin, onların kente tutunabilmelerinde önemli bir işleve sahip olduğu sonucuna varılmaktadır. Gündelikçi kadınların, kendi aralarında örnek bir dayanışmaya sahip olduğu, ortak eğlenip, ortak paylaşımlarda bulunduğu ve aralarında herhangi bir taşeronlaşmaya yer vermedikleri görülmektedir.

Gündelikçi kadınlar düşük eğitim düzeyine sahip olup, yeterli kültürel sermayeden de yoksundurlar. Gündelikçi kadınların alt gelir grubuna mensup oldukları ve çalışan yoksullar kategorisinde yer aldıkları gözlenmektedir. Onların çalışmaya başlamalarında en önemli neden yoksulluktur. Kadınların içinde bulunduğu maddi sıkıntılar ve eğitimsizlik onları gündelikçi piyasasına yönlendirmede öne çıkan olgulardır.

Gündelikçilikte belli bir iş sürekliliğinin ve güvencesinin olmadığı anlaşılmaktadır. Gündelikçi kadınlar asgari ücretten fazla gelir elde etmekte ve vergi ödememektedirler. 
Gündelikçi kadınlar iş güvencesizliğine ve bazı olumsuzluklara rağmen asgari ücretten fazla gelir elde ettikleri, vergi ödemedikleri ve iş saatlerini ve günlerini kendi isteklerine göre düzenleme olanaklarına sahip oldukları için yer aldıkları enformel piyasadan görece memnun gözükmektedirler. Onlar işlerini benimsemiş gözükmekte ve içinde bulundukları durumu meşrulaştırmaktadırlar. Gündelikçi kadınların içinde bulunduğu sınıfsal habitus Swartz’ın (2011: 150) belirttiği gibi, bireyleri düzene itaate yönlendirerek toplumsal ve ekonomik zorunluluğu erdeme dönüştürür. Temel hayat koşullarının sorgusuz sualsiz kabullenilmesini sağlayarak ekonomik ve toplumsal eşitsizliği meşrulaştırır.

Gündelikçi kadınlar eğitimsiz ve vasıfsız olmalarına rağmen ev temizliği işinde çalışmakta, bu iş sayesinde bazı olanaklara kavuşmaktadırlar. Düşük gelirli ailelerine maddi anlamda katkı sağlayarak aile geçimine yardımcı olmaktadırlar. Çalışıyor olmaları kendilerini sosyal ve ekonomik olarak güçlü hissetmelerine, özgüvenlerinin gelişmesine neden olmaktadır. Ayrıca ev temizliği işinde çalışarak çocuklarını okutabilmekte, bu sayede onların ileride sosyal hareketlilik olanağına kavuşabilmelerini sağlamaktadırlar.

Aynı sosyo-ekonomik statüye sahip gündelikçi kadınların beklentilerinin de aynı olduğu ortaya çıkmaktadır. Gündelikçi kadınlar, çocuklarının ileride kendilerinin çektikleri sıkıntıları çekmelerini istememektedirler. Kendileri ve özellikle de çocukları için gelecek kaygısı taşımaktadırlar. Gündelikçi kadınların yukarı doğru sosyal ve mesleki hareketlilik imkanları olmadığı için, çocuklarının gelecekte iyi yerlere gelmesini ummaktadırlar. $\mathrm{Ne}$ var ki, gündelikçi kadınların en büyük gelecek beklentileri çocuklarının okuyup, memur olmasidir. 


\section{KAYNAKÇA}

Bağış, R.C., (2017). Çocuk Emeğine ve Çıraklık Eğitimine Sosyolojik Bir Bakış: Denizli Kent Örneği, (Basılmamış Doktora Tezi), Pamukkale Üniversitesi Sosyal Bilimler Enstitüsü, Denizli.

Bora, A., (2014). Kadınların Sınıfı: Ücretli Ev Emeği ve Kadın Öznelliğinin İnşası, İletişim Yayınları, İstanbul.

Coser, L., (2011). Sosyolojik Düşüncenin Ustaları: Tarihsel ve Toplumsal Bağlamlarında Fikirler, (çev: Himmet Hülür, Serhat Toker ve İbrahim Mazman), De Ki Basım Yayın, Ankara.

Çelik, K. ve Yüce-Tar, Y., (2016). Samsun'da Evlere Temizliğe Giden Roman Kadınlar: Enformel Sektörde Çalışmanın Yükü Nelerden Hafif?, Çalışma ve Toplum, 48 (1), 5986.

De Beauvoir, S., (1974). The Second Sex, Vintage, New York.

Demir, Ö., (2009). “Nitel Araştırma Yöntemleri”, Sosyal Bilimlerde Araştırma Yöntemleri, (ed. Kaan Böke), Alfa Yayınları, İstanbul.

Gönç-Şavran, T., (2009). “Sosyolojide Nicel ve Nitel Araştırma Yöntemleri”, Sosyolojide Araştırma Yöntem ve Teknikleri, Anadolu Üniversitesi Yayını No: 1963, Eskişehir.

Jourdain, A. ve Naulin, S., (2016). Pierre Bourdieu'nün Kuramı ve Sosyolojik Kullanımları, (çev: Öykü Elitez), İletişim Yayınları, İstanbul.

Kalaycıoğlu, S. ve Rittersberger-Tılıç, H., (2001). Evlerimizdeki Gündelikçi Kadınlar: Cömert Ablaların Sadık Hanımları, Su Yayınları, İstanbul.

Momsen-Henshall, J., (1999). “Maids On The Move: Victim Or Victor”, Gender, Migration And Domestic Service, Routledge, London.

Oakley, A., (1975). Women's Work: The Housewife, Past and Present, Pantheon Books, New York.

Özbay, F., (2012). Dünden Bugüne Aile, Kent ve Nüfus, İletişim Yayınları, İstanbul.

Özyeğin, G., (2005). Başkalarının Kiri: Kapıcılar Gündelikçiler ve Kadınlık Halleri, (çev: Suğra Öncü), İletişim Yayınları, İstanbul.

Suğur, N., Suğur, S., Gönç-Şavran, T., Çetin, O. ve Akarçay, E., (2010). Eskişehir'de Çalışan Yoksullar, Enformel İstihdam ve Yoksulluk İlişkileri, Anadolu Üniversitesi Yayınları No: 2030, Eskişehir.

Swartz, D., (2011). Kültür ve İktidar: Pierre Bourdieu'nün Sosyolojisi, (çev: Elçin Gen), İletişim Yayınları, İstanbul.

Ünlütürk, Ç., (2008). "Ev Hizmetlerinin Küreselleşmesi: Türkiye’de Ev Hizmetlerinde Çalışan Göçmen Kadınlar”, Sınıf Çalışmaları Sempozyumu 3: Türkiye İşçi Sınıfı ve Emek Hareketi Küreselleşiyor mu?, Sosyal Araştırmalar Vakfı, İstanbul. 
Yıldırım, A. ve Şimşek, H., (2000). Nitel Araştırma Yöntemleri, Seçkin Yayıncılık, Ankara. Yıldırım, A. ve Şimşek, H., (2005). Sosyal Bilimlerde Araştırma Yöntemleri, Seçkin, Ankara. 